https://doi.org/10.22319/rmcp.v11i1.5018

Article

\title{
Transmission of Anaplasma marginale by unfed Rhipicephalus microplus tick larvae under experimental conditions
}

Itzel Amaro Estrada ${ }^{a}$

Miguel A. García-Ortiz ${ }^{\text {b }}$

Jesús F. Preciado de la Torre ${ }^{\mathrm{a}}$

Edmundo E. Rojas-Ramírez a

Rubén Hernández-Ortiz ${ }^{a}$

Francisco Alpírez-Mendoza ${ }^{c \dagger}$

Sergio D. Rodríguez Camarillo ${ }^{\text {a* }}$

${ }^{a}$ Instituto Nacional de Investigaciones Forestales Agrícolas y Pecuarias (INIFAP). Centro Nacional de Investigación Disciplinaria en Salud Animal e Inocuidad. Tel: +52 7773192860 ext. 125, Fax: +52 7773192850 ext. 129. Carr. Cuernavaca - Cuautla No 8534, Col. Progreso, Jiutepec, Mor. 62550, México.

${ }^{\mathrm{b}}$ Independent Scientist. México.

${ }^{\mathrm{c}}$ INIFAP. Campo Experimental La Posta, Paso del Toro, Veracruz, México.

$\dagger$ This work is dedicated to Dr. Francisco Alpírez Mendoza whom passed away of natural causes while this work was in progress.

*Corresponding author: rodriguez.sergio@inifap.gob.mx; sergeiyevsky@yahoo.com 


\begin{abstract}
:
The current description of biological transmission of Anaplasma marginale by Rhipicephalus microplus ticks, includes of the biological intrastadial and transstadial transmission. Both transovarian transmission of Anaplasma from engorged ticks to their progeny and, transmission from infected unfed larvae to the mammalian host is controversial. In order to demonstrate vertical transmission of $A$. marginale by $R$. microplus ticks under experimental conditions, feed-acquisition infected engorged females were incubated at $18{ }^{\circ} \mathrm{C}$ or $28{ }^{\circ} \mathrm{C}$ for oviposition. Larvae hatched from these ticks were used to infest two steers for each incubation temperature. None of the four steers infested with either lot of larvae developed clinical disease, yet subclinical infection was observed in the steers infested with larvae from engorged ticks incubated at $28^{\circ} \mathrm{C}$ for hatching. gDNA from, larvae used for the infection of the carrier tick donor, gDNA from larvae oviposited at $28{ }^{\circ} \mathrm{C}$, gDNA from blood of $A$. marginale-positive steers, were positive for amplification of $m s p 5$ and $m s p 1 \alpha$ the variable region by PCR. All other DNA samples from the original stabilate, blood from the donor steer, larvae from ticks incubated at $28{ }^{\circ} \mathrm{C}$ and blood from steers infested with these same larvae were positive to both, msp5 and mspl $\alpha$ PCR. mspl $\alpha$ sequences of all PCR products were the same and are consistent with previously reported Tlapacoyan- 2 sequence. The present evidence indicates that $R$. microplus is capable of passing A. marginale to its progeny and that these infected larvae can transmit the infection to susceptible hosts.
\end{abstract}

Key words: Anaplasma marginale, Transovarian transmission, Ticks, Rhipicephalus microplus.

Received: $15 / 08 / 2018$

Accepted: 30/01/2019

\title{
Introduction
}

Ticks are globally widespread ectoparasites and their eco-epidemiology is dependent on the regional environmental conditions ${ }^{(1)}$. Ticks are arthropods with great capacity for transmission of human and animal pathogens and are considered the most important vectors

of disease-causing pathogens in domestic and wild animals second to mosquitoes ${ }^{(1,2)}$. There are many species of ticks present in Mexico $^{(3)}$ but the most economically important in the cattle industry is Rhipicephalus microplus both in Mexico and Latin America. R. microplus 
is responsible for direct damage and transmission of bovine babesiosis and bovine $\operatorname{anaplasmosis}^{(3,4)}$.

While transovarian transmission of bovine babesiosis has been clearly established ${ }^{(5)}$, transovarian transmission of bovine anaplasmosis is still controversial.

Bovine anaplasmosis a rickettsial tick-borne disease of worldwide distribution ${ }^{(6)}$. Anaplasma marginale, the causal agent, infects mature erythrocytes of several ruminant species but it is of greater impact in adult beef cattle; the clinical syndrome includes fever, anemia, losses in weight and production and, death if timely treatment is not $\operatorname{provided}^{(7,8)}$.

In cattle, A. marginale infects mature erythrocytes and endothelial cells ${ }^{(9,10)}$ and, despite specific treatment, cattle may remain as asymptomatic carriers for the rest of their lives ${ }^{(11,12)}$. The emergence of antigenic variants of membrane proteins of the rickettsia in the mammalian host has also been shown to be fundamental for its permanence and transmission to naïve $\operatorname{hosts}^{(13)}$.

Transmission of A. marginale between cattle occurs both mechanically and biologically. Mechanically, by blood sucking arthropods and veterinary procedures that transfer infected blood from carriers to naïve hosts ${ }^{(14,15)}$. Biological transmission is carried mainly by Rhipicephalus and Dermacentor ticks ${ }^{(8)}$ but in Latin America, the cattle tick Rhipicephalus microplus is the main biological vector ${ }^{(4)}$. Ticks can transmit biologically the rickettsia within the same stage (intrastadial) and from one stage to another (transstadial). Tick larvae, nymphs and adults acquire the rickettsia by feeding on cattle and these replicate within $R$. microplus midgut cells ${ }^{(16,17,18)}$. After an initial cycle of replication, tick transmissible Anaplasma strains migrate from the midgut through the hemolymph to other tissues, including the salivary gland acinar cells where the rickettsia undergoes several cycles of final logarithmic replication ${ }^{(19)}$. Upon a second round of feeding, and usually, after molting (transstadial transmission), ticks secrete the infective forms of the rickettsia in their saliva while feeding, thus transmitting the rickettsia $^{(18)}$. Previous evidence has shown that hand-transferred adult $R$. microplus males transmit A. marginale ${ }^{(4,20)}$. A. marginale infected $R$. microplus nymphs and young adults (larvae and nymphs incubated in the laboratory and allowed to molt to the next stage) and hand-transferred to susceptible animals were capable to transmit Mexican Aguascalientes and Yucatan A. marginale strains of high and low virulence respectively in the laboratory ${ }^{(21)}$.

$R$. microplus is a one-host tick which spends its entire parasitic life on the same animal until engorged females drop to lay their eggs. Adult male ticks can migrate through physical contact from one host to another ${ }^{(22,23)}$. Their importance as A. marginale vector between different animals though has not been fully evaluated. The apparent inefficiency of male ticks as transmitters, and the presence of anaplasmosis outbreaks at the beginning of the tick season has led to propose that, larvae of infected ticks may acquire the infection through the ovary 
(transovarian transmission). Larvae are then hatched infected, becoming potential vectors for A. marginale ${ }^{(24)}$. Further experimental efforts to prove transovarian transmission in Dermacentor ticks have been inconclusive ${ }^{(25)}$. In an effort to clarify transovarian transmission in $R$. microplus, Shimada and coworkers ${ }^{(26)}$ collected $R$. microplus larvae from an infected pasture during the first five months of the year in Brazil, and found that 7/50 samples were positive when tested for msp5 by nested PCR (nPCR). In this same study, female ticks engorged on an A. marginale infected carrier were incubated at $18^{\circ} \mathrm{C}$ or $28^{\circ} \mathrm{C}$ for oviposition; eleven percent of larvae from engorged ticks incubated at $18{ }^{\circ} \mathrm{C}$ and none from those incubated at $28{ }^{\circ} \mathrm{C}$ were positive when tested for msp 5 by nPCR. These authors however, make no reference of $m s p 5$-positive larvae from any of these groups to be infested onto susceptible cattle to confirm feed-transmission ${ }^{(26)}$.

In light of these findings it was hypothesized that $R$. microplus larvae can acquire $A$. marginale from their $A$. marginale-engorged progenitor (transovarian transmission) and when incubated at $18{ }^{\circ} \mathrm{C}$ and, through feeding, transmit the infection to uninfected cattle under laboratory conditions

\section{Material and methods}

\section{Ethics statement}

This study was approved by the CENID-PAVET branch of the INIFAP Animal Experimentation and Ethics Committee and conducted considering ethic and methodological aspects in agreement with the Mexican regulations related to use, housing and transport of experimental animals NOM-062-ZOO-1999.

\section{Pathogen and vector strains}

The Anaplasma marginale Tlapacoyan-2 strain used in this study was originally collected in the Municipality of Tlapacoyan, Veracruz state, Mexico, from a natural outbreak and has been characterized with regards to the $m s p l \alpha$ variable region and $m s p 4$ genes $^{(27)}$. This strain has been shown to be transmissible by $R$. microplus adult males in CENID-PAVET laboratory. 
The "Media Joya" colony of $R$. microplus was originally collected from the Tapalpa Municipality, Jalisco State, Mexico ${ }^{(28,29)}$, and is routinely maintained through passages in tick-borne disease-free steers at the CENID-PAVET. The colony efficiently transmits multiple A. marginale strains, including the Tlapacoyan- 2 strain $^{(21)}$. To ascertain that the strain is free of $A$. marginale, ticks from every generation are routinely tested for the absence of $A$. marginale by nPCR for the msp5 gene (see below).

Five 12-month old Bos taurus-cross steers were purchased from a local breeder in the Municipality of Cuauhtémoc, west-central Chihuahua state, Mexico which is classified as tick-free by The Mexican National Service of Health, Safety and Agro-Food Quality (http://www.gob.mx/senasica/documentos/34495). These steers were certified free of tuberculosis and brucellosis by Federally certified laboratories. The animals were tick-free, and were also free of $A$. marginale as certified by endpoint nPCR for $m s p 5$ gene. Steer 027 was purchased first and the remaining four steers (1756, 1776, 6963 and 6964) were purchased later from the same breeder to assure they all met sanitary standards as required by Mexican authorities and our own, with regards to age and absence of ticks and, tick-borne and other infectious diseases.

The CENID-PAVET laboratories and stalls are located on the outskirts, within the city limits of the small urban area of Progreso, in the Jiutepec Municipality of the state of Morelos, central Mexico. The quarters are free of ticks. Tick treatment is required for animals entering these quarters and all animals housed in outdoor stalls are periodically sprayed for fly control. All animals used in these experiments were housed at the Cattle Isolation Unit of the CENIDPAVET, a tick and fly-proof confinement stall.

\section{Infection of carrier animal}

Steer 027 was intravenously inoculated with a dose of $8.2 \times 10^{9}$ infected erythrocytes of $A$. marginale Tlapacoyan-2 strain preserved under liquid nitrogen. The infection was monitored and the animal required no treatment. Steer 027 remained as an asymptomatic carrier as tested both by microscopic examination of Giemsa-stained blood slides and amplification of msp5 gene by nPCR, for the 15 mo prior to infestation with $R$. microplus for this study. Steer 027 was infested with (approximately 10,000) Media-Joya $R$. microplus mature larvae hatched from $0.5 \mathrm{~g}$ of eggs to feed-acquire the infection. Twenty-one (21) days later, mature engorged females were collected directly from steer 027 , rinsed in distilled water to eliminate debris and groups of 10 females were set into petri dishes and incubated at $80 \%$ humidity. 


\section{Incubation for oviposition}

Engorged females were set in two different lots to complete oviposition as follows. The first lot was incubated at $18^{\circ} \mathrm{C}$ for oviposition in a climatized room which is set to have maximal variations of $2{ }^{\circ} \mathrm{C}$. In order to avoid temperature variations due to regular use of the room, ticks were kept within a small portable cooler and $80 \%$ humidity was provided by use of damp wicks and controlled by use of a Traceable ${ }^{\circledR}$ hygrometer (Fisher Scientific). An equal number of dishes were set at $28^{\circ} \mathrm{C}$ for oviposition into a Nor-Lake Scientific incubator (NorLake LRF201WWW-0). Humidity was maintained at $80 \%$ saturation as described. Once oviposition was complete, egg masses from each temperature were pooled, weighted and divided into $0.25 \mathrm{~g}$ lots and kept in $5 \mathrm{ml}$ glass vials capped with cotton plugs. Both egg-lots were incubated at $28{ }^{\circ} \mathrm{C}$ and $80 \%$ humidity as described, for another two weeks until hatching. Mature larvae (approximately 5,000) from $0.25 \mathrm{~g}$ egg-lots were used for feedtransmission on intact steers. Additional mature larvae from $0.25 \mathrm{~g}$ lots from females kept at $18^{\circ} \mathrm{C}$ and $28^{\circ} \mathrm{C}$ were frozen for further determination and identification of $A$. marginale DNA by amplification of $m s p 5$ and $m s p l \alpha$ variable region.

\section{Feed-transmission infection of naïve steers, clinical monitoring, and sample collection}

Four non-splenectomized steers were each infested with mature larvae from $0.25 \mathrm{~g}$ egg lots; steers 1756 and 1776 were infested with larvae from engorged females incubated at $18{ }^{\circ} \mathrm{C}$ while steers 6963 and 6964 were infested with larvae from engorged females incubated at $28^{\circ} \mathrm{C}$.

\section{Clinical monitoring}

Clinical monitoring of experimental animals included daily registration of rectal temperature (between 8 and 9 in the morning), daily collection of blood with anticoagulant by venipuncture of the caudal vein for examination of Giemsa-stained blood smears and evaluation of packed cell volume by the microhematocrit method and weekly amplification of $m s p 5$ gene by nPCR and, mspl $\alpha$ gene variable region by PCR and sequencing ${ }^{(27)}$. 


\section{DNA extraction, PCR, cloning and sequencing}

Larvae from engorged females incubated at $18{ }^{\circ} \mathrm{C}$ and at $28{ }^{\circ} \mathrm{C}$ were used for extraction of genomic DNA (gDNA). Larvae from $100 \mathrm{mg}$ eggs masses were extracted as follows: frozen $\left(-70{ }^{\circ} \mathrm{C}\right)$ larvae were pulverized using a $-70{ }^{\circ} \mathrm{C}$ frozen mortar. The pulverized larvae were then solubilized in $1 \mathrm{M}$ Tris- $\mathrm{HCl}$, $0.5 \mathrm{M}$ EDTA, proteinase $\mathrm{K}(1 \mathrm{mg} / 7 \mathrm{ml})$ solution and centrifuged 10,000 $x \mathrm{~g}$; the supernatant was separated from DNA with two cycles of phenol-chloroform-isoamyl alcohol and chloroform. Supernatants were washed stepwise first with absolute ethanol and then with $70 \%$ ethanol. The DNA was hydrated in double distilled-deionized sterile water and kept frozen at $-20{ }^{\circ} \mathrm{C}$ until use.

Anticoagulated blood samples from transmission-infected steers were centrifuged at 2,250 $\mathrm{xg}$ for $15 \mathrm{~min}$ at $4{ }^{\circ} \mathrm{C}$ : plasma and buffy coat were discarded. gDNA was extracted by means of a commercial kit (UltraClean ${ }^{\circledR}$ BloodSpin ${ }^{\circledR}$ DNA Isolation Kit, MO-BIO Laboratories Inc.), following manufacturer's instructions. gDNA was kept at $-20^{\circ} \mathrm{C}$ until use.

DNA samples from blood and larvae were assayed for $m s p 5$ gene as a universal marker for A. marginale by nested PCR using forward: 5'-GCATAGCCTCCGCGTCTTTC-3' and reverse 5'-TCCTCGCCTTGCCCTCAGA-3' primers in the first round of amplification and forward 5'-TACACGTGCCCTACCGACTTA-3' and reverse 5'-TCCTCGCCTTGCCCTCAGA-3' primers in the second round as described ${ }^{(30)} . m s p 5$ $\mathrm{nPCR}$ was run in two rounds in a $25 \mu \mathrm{l}$ final volume with a commercial kit (PCR master mix, system, Promega, Madison, WI, USA) in a T-Professional Thermocycler (Biometra, Germany), $0.1-1 \mathrm{ng}$ DNA and $10 \mathrm{pM}$ primers. Cycling conditions for $m s p 5$ were a preheating step at $95{ }^{\circ} \mathrm{C}$ for $3 \mathrm{~min}$ and 35 cycles of $95^{\circ} \mathrm{C}$ for $30 \mathrm{~s}, 65^{\circ} \mathrm{C}$ for $58 \mathrm{~s}$, and $72{ }^{\circ} \mathrm{C}$ for $30 \mathrm{~s}$ with final extension step at $72{ }^{\circ} \mathrm{C}$ for $10 \mathrm{~min}$.

$m s p 5$ nPCR positive samples were assayed for the $m s p l \alpha$ variable region by PCR (forward: 5' -GTGCTTATGGCAGACATTTCC-3' and reverse 5'-CTCAACACTCGCAACCTTGG-3' primers) ${ }^{(27,31)}$ for strain verification. For the $m s p 1 \alpha$ variable region cycling conditions were preheating step $95^{\circ} \mathrm{C}$ for $3 \mathrm{~min}$ and 35 cycles $60 \mathrm{~s}$, $58^{\circ} \mathrm{C} 60 \mathrm{~s}, 72^{\circ} \mathrm{C} 60 \mathrm{~s}$, and final extension at $72^{\circ} \mathrm{C}$ for $10 \mathrm{~min}$. nPCR and PCR products were separated in $2 \%$ agarose gels following electrophoresis in $1 \mathrm{x}$ TAE buffer and staining with $0.015 \%$ ethidium bromide at 100 volts. $m s p l \alpha$ variable region PCR products were cloned in pJet1.2 plasmid system using CloneJet PCR cloning kit (Thermo Fisher Scientific), and $E$. coli TOP10 competent cells were transformed with the constructions following manufacturer instructions. Positive colonies were grown in LB+ampicillin $(100 \mathrm{mg} / \mathrm{ml})$ and plasmid DNA was isolated by use of Wizard® Plus SV Minipreps (Promega, Madison WI, USA). Plasmid DNA from at least three isolated colonies was sequenced for determination of the consensus 
sequence. DNA sequences derived from Sanger sequencing were analyzed with ApE Plasmid Editor v2.0.47. Consensus sequences were aligned with ClustalW (http://www.clustal.org/).

\section{Results}

\section{Initial infection and feed-acquisition of Anaplasma marginale}

Intravenous inoculation of steer 027 with A. marginale Tlapacoyan-2 strain resulted in positive blood-smears and mild clinical signs of anaplasmosis $\left(39{ }^{\circ} \mathrm{C}\right.$ rectal temperature, depression, loss of appetite and anemia), reaching a $3.2 \%$ maximal rickettsemia, and a loss of $50 \%$ packed cell volume by d 25 . Chemotherapy was no required and steer 027 returned to normal clinical values within $2 \mathrm{wk}$ after onset of infection. Steer 027 remained as a subclinical carrier for the next $15 \mathrm{mo}$, as corroborated by periodic nPCR for msp5 gene amplification. Mature $R$. microplus larvae negative to A. marginale as determined by msp5 nPCR, were infested on steer 027 for feed-acquisition infection. Engorged females collected $21 \mathrm{~d}$ later and incubated at $28{ }^{\circ} \mathrm{C}$, completed oviposition over $15 \mathrm{~d}$, a period considered normal. In contrast, engorged females collected at the same time but incubated at $18^{\circ} \mathrm{C}$ took over $30 \mathrm{~d}$ to complete oviposition. Regardless of the temperature at which the mothers were incubated, larvae from both lots completed hatching within $15 \mathrm{~d}$ after oviposition.

\section{Feed-Transmission}

Steers were infested with $R$. microplus larvae from engorged females incubated at $18{ }^{\circ} \mathrm{C}$ (steers 1756 and 1776) and $28^{\circ} \mathrm{C}$ (steers 6963 and 6964), respectively. Mature unfed larvae were allowed to feed and reach adult stage on designated steers. None of the four steers developed clinical signs of anaplasmosis or showed infected erythrocytes at microscopic evaluation of blood smears during this period. Eight weeks after infestation, all four animals were subjected to experimental splenectomy in order to immunosuppress and induce rickettsemia. Steer 6964 (larvae oviposited at $28{ }^{\circ} \mathrm{C}$ ) developed a $7.5 \%$ rickettsemia detectable by microscopy recorded $2 \mathrm{~d}$ after splenectomy moment when the animal received specific treatment (oxytetracyclin $20 \mathrm{mg} / \mathrm{kg}$ for three consecutive days). Despite splenectomy, none of the other three steers developed microscopically detectable rickettsemia. msp5 specific nPCR amplification corroborated the presence of $A$. marginale DNA in steers 6964 and 6963 but did not amplify in blood from steers 1756 and 1776 (Figure 1). 
Figure 1: Anaplasma marginale msp5 nPCR detection. nPCR products were separated by electrophoresis in $1 \%$ agarose gel

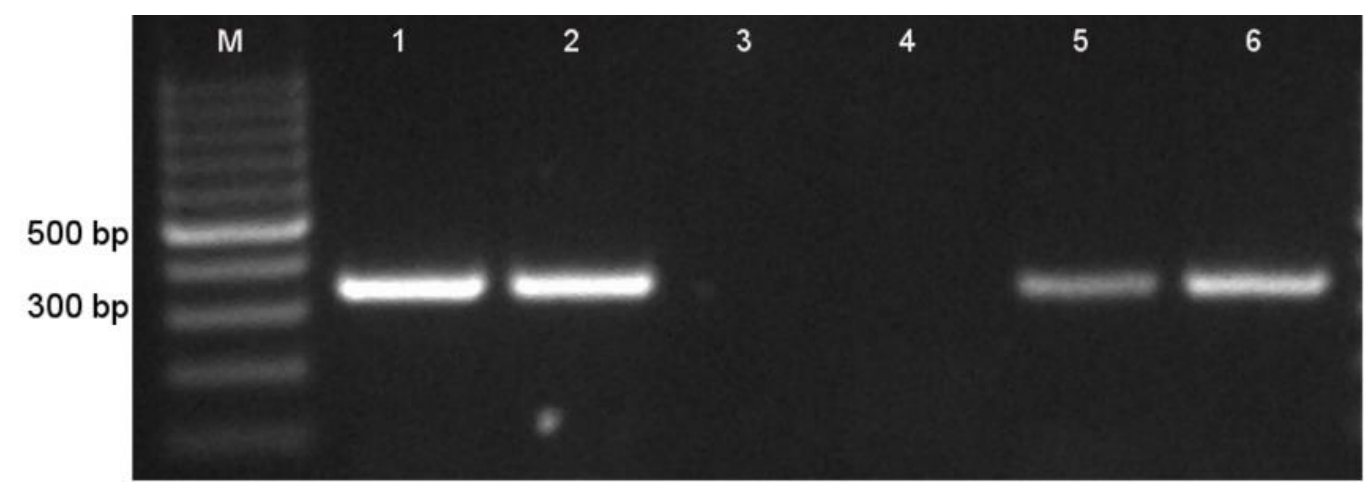

M. Molecular weight marker; 1 , Tlapacoyan-2 original frozen stabilate; 2 , steer $027 ; 3$, steer $1756 ; 4$, steer 1776 ; 5 , steer $6963 ; 6$, steer 6964

In order to corroborate that Tlapacoyan-2 strain was the same pathogen infecting steers 027 , 6964 and 6963, blood samples from these steers, a sample of the original cryopreserved stabilate and, larvae hatched from ticks incubated a $28{ }^{\circ} \mathrm{C}$, were assayed for the $m s p 1 \alpha$ variable region. Figure 2 shows a 750 bp PCR product (lane 2) for Tlapacoyan-2 cryopreserved stabilate, in agreement with the reported sequence ${ }^{(27)}$; (GenBank accession number JN564641.1). A band with the same apparent molecular weight was present in all other samples tested for the variable region of $m s p 1 \alpha$ in blood samples from steers 027 (Lane 3), 6964 (Lane 5) and 6963 (lane 6) and R. microplus larvae from engorged ticks incubated at $28^{\circ} \mathrm{C}$ (Lane 4$)$. 
Figure 2: mspla variable region specific PCR
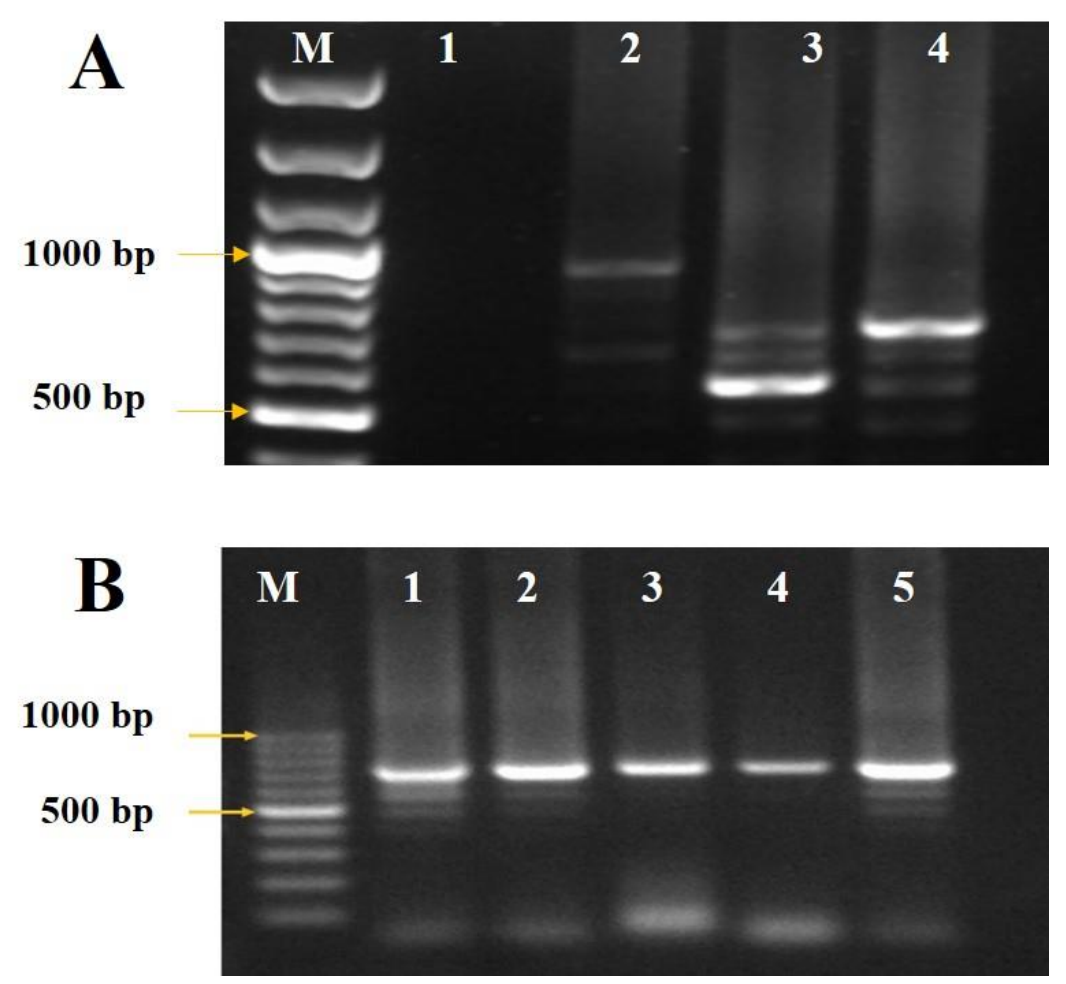

Panel A; M, molecular weight marker; lane 1, (-) control; lane 2(+) control Mex-31 infected blood; lane 3, Tlapacoyan-1 infected blood; lane 4, Tlapacoyan-2 infected blood. Panel B: lane 1, Tlapacoyan-2 cryostabilate; lane 2, steer 027 blood sample; lane 3, steer 6963 week 9 blood sample; lane 4, R. microplus larvae from engorged ticks incubated at $28^{\circ} \mathrm{C}$ and lane 5 , steer 6964 week 9 blood sample.

All sequences derived from either blood or larvae were identical for the mspl $\alpha$ variable region of Tlapacoyan-2 strain as reported ${ }^{(27)}$. This finding is consistent with the hypothesis that $R$. microplus larvae from engorged ticks acquire the infection from their mothers and are capable of transmitting the infection to naïve hosts. It was not demonstrated presence (PCR or blood smear) of A. marginale in either larvae from engorged ticks incubated at $18{ }^{\circ} \mathrm{C}$ nor steers infested with them.

\section{Discussion}

Intrastadial and transstadial transmission of A. marginale during the vector parasitic stages have been well documented in Dermacentor and Rhipicephalus ticks ${ }^{(4,32,33)}$. The role of $R$. microplus ticks as the most important biological vector of Anaplasma marginale in areas where Dermacentor ticks are not present has also been documented ${ }^{(4)}$. Efforts to document 
transovarian transmission however, have been carried without success or have been inconclusive.

Step-wise infestations on splenectomized calves with unfed $R$. microplus larvae from engorged ticks fed on cattle infected with Babesia bovis, B. bigemina, A. marginale and other blood-borne pathogens were carried in Madagascar ${ }^{(34)}$. Patent infection was demonstrated with B. bovis and B. bigemina but not with A. marginale, in these splenectomized calves. In two different studies carried in Australia, unfed larvae hatched from acquisition-fed engorged ticks were used only four days or, four and $15 \mathrm{~d}$ after hatching respectively ${ }^{(23,35)}$; in both cases, engorged females were incubated at $28{ }^{\circ} \mathrm{C}$ to complete oviposition. Infection with $A$. marginale was not corroborated in either of these works. A study carried in Colombia ${ }^{(36)}$, reported transmission of anaplasmosis to naïve 6 mo-old calves by larvae hatched from experimentally acquisition-fed ticks. These authors reported that transmission also occurred when the second-generation larvae were infested on a non-splenectomized steer. The cattle housing conditions for this study however were not fully described. Recently, authors in Brazil $^{(26)}$ documented the presence of $A$. marginale DNA in larvae progeny of engorged ticks collected from anaplasmosis endemic paddocks and unfed larvae from experimentally acquisition-fed females engorged on Anaplasma infected calves. These authors however showed no evidence of infestation of susceptible cattle with msp5 PCR positive larvae.

In order to determine transovarial transmission of $A$. marginale, a range of conditions have been reported for oviposition, length of maturation of "infected larvae", variable values of observable rickettsemia both in naturally or experimentally infected donors, use of intact and splenectomized recipients of unfed larvae and even locations where the studies were conducted.

In order to guaranty that the animals were free of $A$. marginale, they were purchased from a tick-free area and were PCR and serology tested at purchase and right before infection or infestation. Housing conditions for the experimental steers in this study precluded transmission of the rickettsia amongst themselves or from the carrier steer (027) by flies or ticks. In an attempt to replicate natural conditions, a bovine carrier with no detectable rickettsemia fed ticks at the moment of feed-acquisition of progenitor ticks. Conventional 28 ${ }^{\circ} \mathrm{C}$ and low $18{ }^{\circ} \mathrm{C}$ temperatures for oviposition were chosen, as there were reports, that transmission could occur at any of these temperatures ${ }^{(26)}$.

The original hypothesis postulated that incubation of engorged ticks at $18^{\circ} \mathrm{C}$ lengthened the oviposition period in such a manner that allowed $A$. marginale to reach and infect the ovary and therefore the progeny as well. Consistent with previous results, incubation at $18{ }^{\circ} \mathrm{C}$ lengthened the oviposition period twofold compared to conventional $28^{\circ} \mathrm{C}$ incubation ${ }^{(37)}$. It was also confirmed the presence of $A$. marginale DNA in the progeny from acquisition-fed ticks incubated at $28{ }^{\circ} \mathrm{C}$, but not in larvae from ticks incubated at $18{ }^{\circ} \mathrm{C}$ however. Consistent 
with the presence of $A$. marginale DNA in these larvae, it was found that one of the two steers infested with larvae from ticks incubated at $28^{\circ} \mathrm{C}$ developed observable rickettsemia on blood smears (6964) $2 \mathrm{~d}$ after splenectomy. Steer 6963 also infested with the same larvae, was msp5 nPCR positive.

It was hypothesized that infestation with larvae from ticks incubated at $18{ }^{\circ} \mathrm{C}$ would transmit the rickettsia yet the present results show that these larvae failed to induce patent rickettsemia while infestation with larvae from incubation at $28^{\circ} \mathrm{C}$ did. The results however are consistent, with others who used larvae from females engorged on infected cattle and achieved infection to susceptible 6-mo-old cattle ${ }^{(36)}$.

It is unknown why transmission was achieved only from larvae hatched from females incubated at $28^{\circ} \mathrm{C}$ and not from those from mothers incubated at $18^{\circ} \mathrm{C}$, yet the evidence from these and other studies where transmission has failed or achieved infection seem to point towards a phenomenon that may occur under the influence of many variables, including the tick strain, the rickettsial strain and very likely, the genetic makeup of the host and not only from the temperature at which the engorged ticks oviposit their eggs.

This is the first study in which the presence of $A$. marginale DNA in larvae and infested naïve cattle was characterized as the same, indicating that transmission from unfed larvae to susceptible cattle occurred. The possibility of using a $73 \beta \beta \beta \gamma m s p l \alpha$ strain facilitated the follow up of the infection along the experiment. Our results confirmed that Tlapacoyan-2 was the same organism in the carrier, larvae and steers in these experiments.

In light of previous evidence, these results provide additional support for the contention that Anaplasma marginale is transovarially transmitted through $R$. microplus ticks and that these larvae were capable of transmitting the rickettsia to the mammalian host. There are still many questions to answer; more studies will have to be carried to respond them. In the meantime, and based on these results it is important that transovarian transmission of Anaplasma marginale be considered within the $A$. marginale life cycle.

\section{Acknowledgements}

The National Institute for Research on Agriculture, Forestry and Livestock (INIFAP) under agreement SIGI 1128119998 and the National Council for Science and Technology (CONACyT), agreement number 168167, funded this work. The funding sources provided financial support for the conduction of research and preparation of the manuscript. The contents of the manuscript however are the authors' sole responsibility, solely to 
acknowledge this fact. We graciously acknowledge to Dr. Enrique Reynaud Garza from The Instituto de Biotecnología, National University of Mexico for the use of his acclimatized room.

\section{Literature cited:}

1. Brites-Neto J, Duarte KM, Martins TF. Tick-borne infections in human and animal population worldwide. Vet World 2015;8(3):301-15.

2. de la Fuente J, Estrada-Pena A, Venzal JM, Kocan KM, Sonenshine DE. Overview: Ticks as vectors of pathogens that cause disease in humans and animals. Front Biosci 2008;13:6938-6946.

3. Rodríguez-Vivas RI, Grisi L, Pérez de León AA, Silva-Villela H, Torres-Acosta JF, Fragoso Sánchez H, et al. Potential economic impact assessment for cattle parasites in Mexico. Rev Mex Cienc Pecu 2017;8(1):61-74

4. Aguirre DH, Gaido AB, Vinabal AE, De Echaide ST, Guglielmone AA. Transmission of Anaplasma marginale with adult Boophilus microplus ticks fed as nymphs on calves with different levels of rickettsaemia. Parasite 1994;1(4):405-407.

5. Mahoney DF, Mirre GB. The selection of larvae of Boophilus microplus infected with Babesia bovis (syn B. argentina). Res Vet Sci 1977;23(1):126-127.

6. Rodríguez SD, García-Ortiz MA, Jiménez-Ocampo R, Vega-y-Murguía CA. Molecular epidemiology of bovine anaplasmosis with a particular focus in Mexico. Infect Genet Evol 2009;9:1092-1101.

7. Aubry P, Geale DW. A review of bovine anaplasmosis. Transbound Emerg Dis 2011;58:1-30.

8. Kocan KM, de la Fuente J, Blouin EF, Coetzee JF, Ewing SA. The natural history of Anaplasma marginale. Vet Parasitol 2010;167(2-4):95-107.

9. Allen PC, Kuttler KL, Amerault TE. Clinical chemistry of anaplasmosis: blood chemical changes in infected mature cows. Am J Vet Res 1981;42(2):326-328.

10. Carreño AD, Alleman AR, Barbet AF, Palmer GH, Noh SM, Johnson CM. In vivo endothelial cell infection by Anaplasma marginale. Vet Pathol 2007;44(1):116-118. Erratum in: Vet Pathol 2007;44(3):427.

11. Magonigle RA, Newby TJ. Elimination of naturally acquired chronic Anaplasma marginale infections with a long-acting oxytetracycline injectable. Am J Vet Res 1982;43(12):2170-2172. 
12. Reinbold JB, Coetzee JF, Hollis LC, Nickell JS, Riegel C, Olson KC, et al. The efficacy of three chlortetracycline regimens in the treatment of persistent Anaplasma marginale infection. Vet Microbiol 2010;145:69-75.

13. Palmer GH, Brayton KA. Antigenic variation and transmission fitness as drivers of bacterial strain structure. Cell Microbiol 2013;15(12):1969-1975.

14. Reinbold JB, Coetzee JF, Hollis LC, Nickell JS, Riegel CM, Christopher JA, et al. Comparison of iatrogenic transmission of Anaplasma marginale in Holstein steers via needle and needle-free injection techniques. Am J Vet Res 2010;71:1178-1188.

15. Scoles GA, Broce AB, Lysyk TJ, Palmer GH. Relative efficiency of biological transmission of Anaplasma marginale (Rickettsiales: Anaplasmataceae) by Dermacentor andersoni (Acari: Ixodidae) compared with mechanical transmission by Stomoxys calcitrans (Diptera: Muscidae). J Med Entomol 2005;42(4):668-675.

16. Futse JE, Ueti MW, Knowles DP Jr, Palmer GH. Transmission of Anaplasma marginale by Boophilus microplus: retention of vector competence in the absence of vectorpathogen interaction. J Clin Microbiol 2003;41(8):3829-3834.

17. Kocan KM, Goff WL, Stiller D, Edwards W, Ewing SA, Claypool PL, et al. Development of Anaplasma marginale in salivary glands of male Dermacentor andersoni. Am J Vet Res 1993;54(1):107-112.

18. Ueti MW, Reagan JO Jr, Knowles DP Jr, Scoles GA, Shkap V, Palmer GH. Identification of midgut and salivary glands as specific and distinct barriers to efficient tick-borne transmission of Anaplasma marginale. Infect Immun 2007;75(6):2959-2964.

19. Scoles GA, Ueti MW, Noh SM, Knowles DP, Palmer GH. Conservation of transmission phenotype of Anaplasma marginale (Rickettsiales: Anaplasmataceae) strains among Dermacentor and Rhipicephalus ticks (Acari: Ixodidae). J Med Entomol 2007;44(3):484-491.

20. Dalgliesh RJ, Stewart NP. The use of tick transmission by Boophilus microplus to isolate pure strains of Babesia bovis, Babesia bigemina and Anaplasma marginale from cattle with mixed infections. Vet Parasitol 1983;13(4):317-323.

21. Mora C, Pérez M, García-Ortiz MA, Rojas-Ramírez EE, Preciado-de -la-Torre JF, Hernández R, et al. Evaluación de la transmisión de dos cepas mexicanas de Anaplasma marginale por la garrapata Boophilus microplus, in: XIII Congreso Lationamericano de Buiatría. 2007:241-245.

22. Mason CA, Norval RAI. The transfer of Boophilus microplus (Acarina: Ixodidae) from infested to uninfested cattle under field conditions. Vet Parasitol 1981;8:185-188. 
23. Connell M, Hall WT. Transmission of Anaplasma marginale by the cattle tick Boophilus microplus. Aust Vet J 1972;48(8):477.

24. Piercy PL. Transmission of anaplasmosis. Ann NY Acad Sci 1956;64:40-48.

25. Stich RW, Kocan KM, Palmer GH, Ewing SA, Hair JA, Barron SJ. Transstadial and attempted transovarial transmission of Anaplasma marginale by Dermacentor variabilis. Am J Vet Res 1989;50(8):1377-1380.

26. Shimada MK, Yamamura MH, Kawasaki PM, Tamekuni K, Igarashi M, Vidotto O, et al. Detection of Anaplasma marginale DNA in larvae of Boophilus microplus ticks by polymerase chain reaction. Ann N Y Acad Sci 2004;1026:95-102.

27. Jiménez-Ocampo R, Vega y Murguía CA, Oviedo N, Rojas-Ramírez EE, García-Ortiz MA, Preciado-de-la-Torre JF, et al. Genetic diversity of the $m s p l \alpha$ gene variable region and msp4 gene of Anaplasma marginale strains from Mexico. Rev Mex Cienc Pecu 2012;3:373-387.

28. Gaxiola-Camacho S, García-Vázquez Z, Cruz-Vázquez C, Portillo-Loera J, VázquezPeláez C, Quintero-Martínez MT, et al. Comparison of efficiency and reproductive aptitude indexes between a reference and field strains of the cattle tick Rhipicephalus (Boophilus) microplus, in Sinaloa, Mexico. Rev Bras Parasitol Vet 2009;18(4):9-13.

29. Merino O, Antunes S, Mosqueda J, Moreno-Cid JA, Pérez de la Lastra JM, Rosario-Cruz $\mathrm{R}$, et al. Vaccination with proteins involved in tick-pathogen interactions reduces vector infestations and pathogen infection. Vaccine 2013;31(49):5889-5896.

30. Torioni de Echaide S, Knowles DP, McGuire TC, Palmer GH, Suarez CE, McElwain TF. Detection of cattle naturally infected with Anaplasma marginale in a region of endemicity by nested PCR and a competitive enzyme-linked immunosorbent assay using recombinant major surface protein 5. J Clin Microbiol 1998;36(3):777-782.

31. Palmer GH, Knowles DP Jr, Rodriguez JL, Gnad DP, Hollis LC, Marston T, et al. Stochastic transmission of multiple genotypically distinct Anaplasma marginale strains in a herd with high prevalence of Anaplasma infection. J Clin Microbiol 2004;42(11):5381-5384.

32. Corrier DE, Kuttler KL, Terry MK. Observations on anaplasmosis following field exposure to heavy and light infestations with Boophilus microplus. Vet Parasitol $1983 ; 13,187-190$.

33. Rogers RJ, Shiels IA. Epidemiology and control of anaplasmosis in Australia. J S Afr Vet Assoc 1979;50(4):363-366. 
34. Uilenberg $\mathrm{G}$ [Note on babesisasis and anaplasmosis in cattle on Madagascar. I. Introduction. Transmission]. Rev Elev Med Vet Pays Trop 1968;21(4):467-474.

35. Leatch G. Preliminary studies on the transmission of Anaplasma marginale by Boophilus microplus. Aust Vet J 1973;49:16-19.

36. López-Valencia G, Vizcaíno-Gerdts O. Transmisión transovárica de Anaplasma marginale por la garrapata Boophilus microplus. Rev ICA Colombia 1992;27:437-443.

37. Esteves E, Pohl PC, Klafke GM, Reck J, Fogaça AC, Martins JR, et al. Low temperature affects cattle tick reproduction but does not lead to transovarial transmission of Anaplasma marginale. Vet Parasitol 2015;214(3-4):322-326. 